
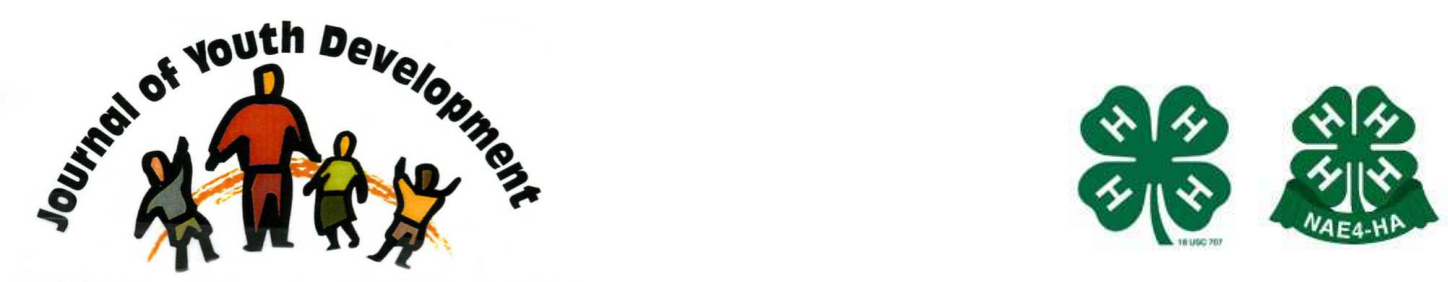

Bridging Research \& Practice

\title{
Benchmarking the Kansas 4-H Judging System
}

\author{
Amy M. Taylor \\ 4-H Youth Development \\ Kansas State Research and Extension \\ Dodge City, KS \\ amtaylor@ksu.edu
}

Cindy Blackwell

Agricultural Education, Communications \& Leadership

Oklahoma State University

Stillwater, OK

cindy.blackwell@okstate.edu 


\title{
JOURNAL OF YOUTH DEVELOPMENT \\ bridging research and practice

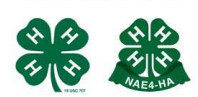

Volume 4, Number 4, Winter 2009

Article 090404PA001

\section{Benchmarking the Kansas 4-H Judging System}

\author{
Amy M. Taylor \\ Kansas State Research and Extension \\ Cindy Blackwell \\ Oklahoma State University
}

\begin{abstract}
This study investigated the methods and policies associated with 4-H project judging at the county level within the Kansas 4-H Program. Extension Agents surveyed about current 4-H judging processes indicated a variety of methods used. Data collected showed that $21.8 \%$ of the counties surveyed practiced some type of project judging without the 4- $\mathrm{H}$ member present. In regard to feedback received by the youth in non-livestock project judging, $64.1 \%$ of counties reported both verbal and written forms of feedback, with $25.6 \%$ receiving only verbal. In livestock project judging, $93.8 \%$ reported that youth receive feedback only verbally. The majority of non-livestock projects are judged using the Danish system, while the number of livestock projects judged are split among both the Danish system and peer system of competitive judging. It was concluded that a wide-variety of judging methods are used, resulting in incongruent programs offered to $4-\mathrm{H}$ members.
\end{abstract}

\section{Introduction}

Since the turn of the 20th century, boys and girls across America have been participating in what is known as the 4-H Youth Development program. In the early 1900's USDA officials sought to educate farmers and homemakers about better practices to improve their living conditions. One way to achieve this was to teach the children in the hope that they would in turn teach their parents. Boys and girls who participated in 4-H club work learned new, effective practices for both the farm and the home, ultimately teaching their parents the same new skills. 4-H club work came about from the efforts of many. School teachers, scientists, government officials, and concerned community members all played an important role in shaping the 4-H program (Wessel \& Wessel, 1982).

Traditionally 4-H was an organization for America's rural youth; boys participated in corn clubs and girls in cooking and sewing clubs (Wessel \& Wessel, 1982). Over the years, the 4-H 
program has grown and expanded from a small, rural youth organization to the largest nonformal youth development organization in the world. While the traditional community club program is still the root of the organization, military clubs, after school programming, and other non-traditional programs are just as effective in many urban and suburban locations. Within the traditional community club program, youth typically engage in monthly club meetings, with additional project meetings, day camps, and social outings. 4-H strives to instill life skills within every member, utilizing project areas to facilitate this learning. The 4-H project experience most often culminates at the county fair, either in a show ring or similar competitive judging process (Ladewig \& Thomas, 1987).

According to Wessel and Wessel (1982), the use and value of competitions in 4-H dates back to agricultural clubs and contests created around the beginning of the 20th century. In a national study of former 4-H members, 4-H programs were indicated as having used competitive events and activities as a means to promote learning and the development of specific skills of 4-H members (Ladewig \& Thomas, 1987). Researchers have indicated that one of the most utilized teaching methods of 4-H has been to provide educational opportunities for youth through competitive activities (Keith \& Vaughn, 1998; Weber \& McCullers, 1986). Much debate has risen over the positives and negatives of competition and its system of rewards. Weber and McCullers (1986) point out that the 4-H system of competition and rewards have been very successful for over 70 years. However, others argue that competition is a system that creates few winners and many losers (Fetsch \& Yang, 2002).

"It has been well documented that American children place great value on winning over others" (Ames, 1981, p. 274). Like many youth programs, 4-H has utilized competition as an appropriate teaching-learning strategy (Allen, Iyechad, Mayeske, Parsons, Rodriguez, Singh, et al., 1989). Radhakrishna, Everhart, and Sinasky (2006) found that 4-H participants believed that 4-H competitive events were avenues to help them learn new things, develop life skills, set goals, and strive for excellence. In addition, competitions prepare youth for a competitive world, and motivate them to strive for excellence (Ladewig \& Thomas, 1987; Weber \& McCullers, 1986; Wessel \& Wessel, 1982).

In a meta analysis of 122 studies on cooperation versus competition, researchers found that "cooperation is considerably more effective than interpersonal competition and individualistic efforts in promoting achievement and productivity" (Johnson, Maruyama, Johnson, Nelson, \& Skon, 1981, p. 51). Prvulovich (1982) argued that it is the innate differences in children's intellect, physical ability, and social capability that breeds competition itself; that competition in essence, is a natural process that enhances the original being. Radhakrishna (2006) pointed out that "competitions contribute to learning democratic values, combating juvenile delinquency, fostering responsible social behaviors...stimulating creativity...and developing life skills" (p. 71). Many studies discuss that competition prepares youth for a competitive world, while stimulating intrinsic motivation (Fetsch \& Yang, 2002; Keith \& Vaughn, 1998; Ladewig \& Thomas, 1987; Weber \& McCullers, 1986).

Radhakrishna (2006) found that parents strongly agreed with many positive statements regarding $4-\mathrm{H}$ competition. In studies designed to determined life skills learned through competitive 4-H projects, parents perceived many benefits, such as responsibility, setting goals, self motivation, social relations, and the development of character (Boleman, Cummings, \& Briers, 2004; Davis, Kieth, Williams, \& Fraze, 2000; Kieth \& Vaughn, 1998). 4-H members themselves reported that they enjoyed competition and that it motivated them to strive for excellence (Radhakrishna, Everhart, \& Sinasky, 2006). 
In opposition, the literature revealed that parents were concerned with negative outcomes of 4-H competition, such as aggressive behavior, cheating, and the development of unhealthy practices, and financial greed (Kieth \& Vaughn, 1998; Radhakrishna, 2006). Youth were also concerned about excessive parent involvement, unethical practices, and unhealthy characteristics that were prevalent in some competitive events (Radhakrishna et al., 2006). The National USDA/ES Task Force Report on Competitions found that research on competition in 4-H to be limited and lacking in psychological or educational concepts (Allen et al., 1989). Many researchers have recommended that all 4-H competitive events should be revisited and modified to mirror the current changes that are occurring in 4-H programs and the way competitive events are structured and implemented (Allen et al., 1989).

Ames (1981) points out that the desire to win may overshadow any value found in that of an excellent performance in a cooperative setting. The literature also showed that "rewards may cause an individual to avoid difficult and challenging tasks" (Weber \& McCullers, 1986, para. 11). In a study to determine factors which influence 4-H participation, researchers found that youth were concerned about "the inequity of judging activities exhibited through criteria" (Cano \& Bankston, 1992, p. 26). These inequities may play a factor in re-enrollment, member satisfaction, and life skills learned. Smith and Collins (1988) also found similar results; their study determined youth attitudes toward competition, and found that they had statistically significant negative attitudes. On the other hand, interpersonal competition has shown its advantages, allowing children to perform new skills, apply knowledge, and practice in real world settings (McTighe, 1997).

\section{Theoretical Framework}

Because the 4-H program encompasses youth of varying ages and stages, it is important that the activities offered are age appropriate (Karns \& Myers-Walls, 1996). The theoretical framework behind this study is that of Erikson's psychodynamic approach. His theories focused on how healthy personalities develop through stages of crisis (Bergen, 2008). Erikson (1963) studied how social factors during childhood play out in the forming of a healthy psychological development as an adult.

Erikson outlined eight stages of psychosocial development, known as the Eight Ages of Man, each that have two opposite extreme outcomes. The eight stages include:

1. trust versus mistrust (ages $0-1$ ),

2. autonomy versus shame and doubt (ages 2-3),

3. initiative versus guilt (ages 3-6),

4. industry versus inferiority (6-12),

5. identity versus identity diffusion (ages 12-18),

6. intimacy versus isolation (20's),

7. generativity versus stagnation ( 20 's-50's), and

8. integrity versus despair (50's and beyond) (Green, 1989).

In Erikson's fourth stage, Industry vs. Inferiority (ages 6-12), children learn to produce good work, which in turn, gives them satisfaction (Bergen, 2008). Erikson (1963) stated that "the child's danger, at this stage, lies in a sense of inadequacy and inferiority" (p. 260). It is a social stage, in which if children experience unresolved feelings of inadequacy, they can suffer from 
serious competence and self-esteem issues. In this stage, the crisis requires the child to learn cooperatively, completing tasks assigned by parents or teachers; if the tasks require greater competencies than the child has mastered, feelings of failure and inferiority may occur (Green, 1989).

If the Cooperative Extension Service stems from research-based information and initiatives, then the 4-H Youth Development programs must follow suit (CSREES, 2006). The 4-H program model consists of four components:

(a) positive relationships with a caring adult,

(b) a safe environment,

(c) opportunities for youth to develop mastery, and

(d) the ability to demonstrate acquired skills (CSREES, 2006).

Nationally, the 4-H program has adopted an experiential learning model as their delivery mode. "Learning by doing" is an important part of the 4-H mission, encouraging youth to learn as they experience and process new knowledge and skills with limited adult guidance (Diem, 2004). By utilizing the Experiential Learning Model, youth advance through five steps to fully learn new skills and knowledge: 1) experience, 2) share, 3) process, 4) generalize, and 5) apply. This model is designed for children of all ages and developmental stages (Diem, 2001).

\section{Definition of Terms}

Terms for many of the methods discussed may vary from region to region. In order to fully understand the following methods and research findings, the following definitions are provided.

Peer Competition: Judging method in which a 4-H member's project work is being compared to another's (Bethard, 1994).

Danish System: A method of evaluating 4-H exhibits based upon a set of standard created for that specific project area. Entries are categorized into one of three groups reflecting how closely the exhibit met the created standards. Three categories exist: blue award- excellent work, exceeds standards; red award- good work, meets standards; and white award- needs improvement, does not meet standards (Newman, 2006).

Exhibit Judging: A judging method based upon the exhibit only and how the exhibit meets set standards, without the member present (Bethard, 1994).

Conference Style: An evaluation method designed to stimulate conversation between the judge and 4-H member; an exchange of knowledge and project experience (Million \& Taylor, 2000).

Lifeskills: Skills that are abilities in which youth learn that are necessary and will help them lead a productive adult life (Friedman, 1994, p. 107).

\section{Purpose \& Objectives}

The need for this study arose from the obligation to ensure that 4- $\mathrm{H}$ youth are benefiting from a safe and positive learning environment throughout the 4-H project judging experience. This coincides with several of the Essential Elements of 4-H Youth Development as outlined by Kress (2004): positive relationship with a caring adult, a safe environment, engagement in learning, and opportunity for mastery. Several judging methods are used throughout the Kansas 4-H 
program, some of which create a competitive learning atmosphere. The literature reveals problems with certain competitive environments that are currently used. The purpose of this study was to benchmark county fair $4-\mathrm{H}$ judging practices currently used in the Kansas 4- $\mathrm{H}$ program. The study addressed the following research questions:

1. At what age are $4-\mathrm{H}$ members eligible to participate in competitive events?

2. Are youth present during project judging?

3. Do youth receive feedback upon completion of project judging?

4. Are exhibits judged upon standards using the Danish System?

\section{Methods}

The population for this study included all Kansas Extension agents with 4-H programming responsibility. Seeing as though one county may have more than one Extension Agent with 4-H responsibility, and to avoid multiple responses per county, one agent was randomly selected from each county for the purpose of this study. Due to the nature of this study, the web-based survey used a proportionate stratified random sampling design, with $n=105$.

A survey instrument consisting of 8 questions was developed to benchmark the current judging methods used at county fairs within the Kansas 4-H program. As Creswell (2008) mentioned, "Instances where surveys are most suitable are to assess trends or characteristics of a population; learn about individual attitudes, opinions, beliefs, and practices...." (p. 414). The first portion of the instrument was designed to assess the current non-livestock 4-H project judging methods used by the county, with the second assessing 4-H livestock project judging methods. The survey instrument was reviewed by a panel of experts to address face and content validity. In addition, a panel of 15 experts within the Oklahoma State University Extension Service pilot tested the instrument in September of 2008 to determine construct validity. It was assumed that all Extensions agents in Kansas had high speed Internet access; this largely reduced the technology threat to effective measurement, as outlined by Dillman and Smyth (2007).

Due to the nature of this report, the study should not be generalized to populations outside of the Kansas 4-H program. This study did not attempt to document the best practice or make causal statements among the variables. Data was not collected on state or regional 4-H programs or contests; this study focused on the 4-H judging methods and processes used at county fairs pertaining to 4-H project work. For the purpose of this study, the researcher assumed that Kansas Extension Agents have an accurate account of what judging methods are currently being used within their 4-H program at their county fair. The researcher also assumed that every county 4-H program is using competitive events as a teaching/learning strategy.

\section{Results}

Eighty-one surveys were completed out of a possible 105 counties, resulting in a $77 \%$ response rate. Of those Extension Agents completing the survey, $58.8 \%$ had a $4-\mathrm{H}$ youth development program focus, $43.8 \%$ agriculture program focus, and $18.8 \%$ family and consumer science (FCS) program focus. With many single agent counties having agricultural and natural resource agents, this explains the relatively low representation of FCS agents in the study.

The first research question in this study was designed to benchmark the age of 4-H members when they become eligible to participate in competitive events. In both non-livestock and 
livestock 4-H projects, the overwhelming majority was seven years old. Only one county responded with an age of 8 , resulting in $98.8 \%$ of agents reporting age seven for non-livestock projects, and $100 \%$ of agents reporting age seven for livestock projects.

The second research question benchmarked the 4-H member's presence at the time of judging. In non-livestock $4-\mathrm{H}$ project areas (i.e. foods, photography, visual arts, etc), $78.2 \%$ of agents reported they utilize the conference style of judging, where the youth member is present. Another $2.6 \%$ of agents reported the use of exhibit style judging, where the child is completely absent from the judging process. The remaining $19.2 \%$ of agents reported some mixture of both methods, with some project areas judged in the absence of the member and some judged in their presence. Projects repeatedly mentioned using the conference style of judging includes: clothing, photography, and foods. 4-H project areas such as woodworking, entomology, posters, electricity, were often noted as being judged without the member present.

Research question three benchmarked the feedback that youth received from judges. Table 1 summarizes these findings. Several of the respondents noted that only the non-livestock projects judged conference style received feedback, while the other project areas did not. The eight agents who reported "other" in non-livestock projects used a combination of verbal and written feedback, varying by the project area. The four agents who reported "other" in livestock projects provided written feedback in projects such as dog, bucket calves, and rabbits only.

Table 1

Feedback received by youth during project exhibit judging

\begin{tabular}{|lcc|}
\hline & $\begin{array}{c}\text { Non-livestock project areas, } \\
\text { number of respondents }\end{array}$ & $\begin{array}{l}\text { Livestock project areas, } \\
\text { number of respondents }\end{array}$ \\
Verbal feedback only & 20 & 71 \\
Written feedback only & 0 & 0 \\
Both, verbal and written & 9 & 1 \\
No feedback & 0 & 0 \\
Other & 8 & 4 \\
\hline
\end{tabular}

The fourth research question in this study was developed to benchmark the system on which projects are judged. Table 2 summarizes these findings. A majority of the respondents who chose "other" further explained that many of their projects are judged according to the Danish system, but champions are picked using peer competition. For example, out of a class of ten, five blues may be awarded, along with five red, utilizing the Danish system judging the exhibits on individual merit against a set standards. Then, utilizing peer competition, the judge takes the five blues, compares them against each other, and finally picks the top two projects that then receive champion and reserve champion. This dual method was reported in both livestock and non-livestock project areas. 
Table 2

Judging method used to evaluate exhibits

\begin{tabular}{|lcc|}
\hline & $\begin{array}{c}\text { Non-livestock project areas, } \\
\text { number of respondents }\end{array}$ & $\begin{array}{l}\text { Livestock project areas, } \\
\text { number of respondents }\end{array}$ \\
Peer competition & 1 & 15 \\
Danish system & 65 & 48 \\
Other & 12 & 16 \\
\hline
\end{tabular}

\section{Discussion \& Implications}

It is concluded that a variety of methods are used in 4- $\mathrm{H}$ project judging at the county-level across the state of Kansas. The incongruence is not only county to county, but within each county from project to project. While a large majority of counties followed the same age guidelines, vast differences occurred in the member's presence and how the project itself was judged. These differences provide diverse experiences for $4-\mathrm{H}$ members across the state. The competitive experience of one 4- $\mathrm{H}$ member can greatly differ from that of a member in a different county, and the educational outcomes of the project exhibit can also widely vary.

With almost $22 \%$ of the counties surveyed reporting that several projects areas are judged without the member present, concern is raised. The child's absence from the project judging contradicts the experiential learning model, the cornerstone of the 4-H educational mission. The member misses out on the opportunity to share and process the project exhibit, two key steps in the experiential learning model (Diem, 2001). If county fair 4-H project judging is so widely experienced by so many members, and if agents are not effectively utilizing the experiential learning model in the majority of project areas and counties, then the following question remains: is Kansas 4- $\mathrm{H}$ missing the mark by not fully utilizing the experiential learning process?

While not abundant in the literature, research on the effective utilization of the Danish system could alleviate some of the risks and potentially negative outcomes of competition. When using the Danish system of judging, projects are not compared against one another, but rather judged against a set of standards (Bethard, 1994). Each exhibit may receive a ribbon. An excellent rating receives a blue, a red ribbon signifies very good work, and a white may mean improvement is needed. According to Bethard (1994), "The purpose of using the Danish judging system is to give every $4-\mathrm{H}$ member the recognition deserved for the work that was done" ( $\mathrm{p}$. 426).

In addition, a conference style judging system could also be used to enhance the benefits of the Danish system. In this setting, the judge interviews the 4-H member while he or she evaluates the exhibit. Judges give both written and verbal feedback and concentrate on the knowledge learned by the youth. 4- $\mathrm{H}$ members are given an opportunity to explain their exhibit using their public speaking skills, interact one on one with an adult, and gain insight as to how to improve for the future (Million \& Taylor, 2000). Other factors that contribute to the judging systems success may include the judges themselves, the county agent, the parent's understanding, room set-up, etc. Many factors play a role in the success of the 4-H member's project judging. To the best of the ability of those involved, risks should be minimized in order to meet the critical elements upon which the organization is based upon. 


\section{Conclusion}

This study reveals areas in need of further research. Statistical data is currently lacking regarding the number of youth participating in 4-H project judging at the county level. While it is known how many youth participate in community clubs, after-school and in-school programs, and military clubs, data does not exist correlating them to project exhibition at the county fair. Future research should also be done to determine 4-H member participation in project exhibition at the county fair in relation to their participation in other club activities. This data could provide future direction in prioritizing program areas of need. In addition, further research on the judging methods and their effectiveness should be studied.

The years between ages six and twelve present a crucial point in the development of young person. Erikson's theories (1963) relate the importance of each crisis at each developmental stage, and competition within 4-H is no exception. The 4-H project judging experience offers opportunities to successfully develop feelings of adequacy and productivity through cooperation. While the there is sufficient literature discussing the impact of competition on youth, there is a lack of information regarding the methods in which to deliver such learning methods. Extension work, 4-H youth development programs included, is researched-based; with this said, there is a void in the body of literature directly related to one of the most popular learning opportunities experienced by many youth.

\section{References}

Allen, J., Iyechad, T., Mayeske, G., Parsons, J., Rodriguez, J., Singh, F., et al. (1989). Competition in 4-H: A national USDA/ES task force report. Available from the National 4-H Council, 7100 Connecticut Ave., Chevy Chase, MD 20815.

Ames, C. (1981). Competitive versus cooperative reward structures: the influence of individual and group performance factors on achievement attributions and affect. American Educational Research Journal, 18(3), 273-287.

Bergen, D. (2008). Human Development: Traditional and Contemporary Theories. New Jersey: Pearson Prentice Hall.

Bethard, G. (1994). Understanding of 4-H judging. In New Jersey 4-H Leader Training Series, Section IV: Understanding Youth and Their Needs. New Brunswick, NJ: Rutgers Cooperative Extension.

Boleman, C.T., Cummings, S.R., \& Briers, G.E. (2004). Parents' perceptions of life skills gained by youth participating in the 4-H beef project. Journal of Extension, 42(5).

Cano, J., \& Bankston, J. (1992). Factors which influence participation and non-participation of ethnic minority youth in Ohio 4-H programs. Journal of Agricultural Education, 33(1), 23-29.

CSREES. (2006). 4-H Youth Development Theoretical Framework. Retrieved on October 18, 2007 from http://www.national4hheadquarters.gov/library/4h docs.htm

Creswell, J.W. (2008). Educational research: Planning, conducting, and evaluating quantitative and qualitative research. Upper Saddle River, NJ: Pearson Education, Inc. 
Davis, C., Kieth, L., Williams, K., \& Fraze, S. (2000). Validation of the perceived benefits of competitive livestock exhibition by Texas 4-H members: A qualitative study. Journal of Southern Agricultural Education Research, 50(1), 119-125.

Diem, K.G. (2001). Leader Training Series: Learn by Doing the 4-H Way (Publication 454). New Brunswick, NJ: Rutgers Cooperative Extension.

Diem, K.G. (2004). Leader Training Series: The Learn-By-Doing Approach to Life Skill

Development (Fact Sheet 891). New Brunswick, NJ: Rutgers Cooperative Extension.

Dillman, D.A., \& Smyth, J.D. (2007). Design effects in the transition to web-based surveys. American Journal of Preventive Medicine, 32(5s), p. 90-96.

Erikson, E.H. (1963). Childhood and Society ( $2^{\text {nd }}$ ed. $)$. New York: Norton.

Fetsch, R.J., \& Yang, R.K. (2002). The effect of competitive and cooperative learning preferences on children's self-perceptions: A comparison of 4- $\mathrm{H}$ and non-4-H members. Journal of Extension, 40(3).

Friedman, R.J. (1994). Lifeskills in the 4-H Program. In New Jersey 4-H Leader Training Series, Section I: This is 4-H. New Brunswick, NJ: Rutgers Cooperative Extension.

Green, M. (1989). Theories of human development: a comparative approach. Englewood Cliffs, NJ: Prentice Hall.

Johnson, D.W., Maruyama, G., Johnson, R., Nelson, D., \& Skon, L. (1981). Effects of cooperative, competitive, and individualistic goal structures on achievement: a meta-analysis. Psychological Bulletin, 89(1), 47-62.

Karns, J. \& Myers-Walls, J.A. (1996) Ages and Stages of Child and Youth Development: A Guide for 4-H Leaders. Purdue University.

Kieth, L., \& Vaughn, P. (1998). The value of 4-H competitive activities as perceived by the parents of 4-H members. Journal of Agricultural Education, 39(3), 41-50.

Kress, C. (2004). Essential Elements of 4-H Youth Development. Retrieved November 5, 2008 from National 4-H Headquarters Website:

http://www.national4hheadquarters.gov/library/4h presents.htm

Ladewig, H., \& Thomas, J.K. (1987). Assessing the impact of 4-H on former members. College State, TX: Texas A \& M University System.

McTighe, J. (1997). What happens between assessments? Educational Leadership, 54(4), 6-12.

Million, B., \& Taylor, J.M. (2000). Conference judging: A message to judges. Retrieved April 18, 2008, from University of Illinois, 4-H Youth Development Web site:

http://www.4-h.uiuc.edu/staff/cjudjud.doc 
Newman, J.A. (2006). Who gets the blue ribbon? Retrieved April 10, 2008, from Washington State University, 4-H Youth Development Web site: http://4h.wsu.edu/projects/danishsys.htm

Prvulovich, Z.R. (1982). In defense of competition. Journal of Philosophy of Education, 16(1), 77-88.

Radhakrishna, R.B. (2006). Educational value of 4-H competitive events as perceived by parents of 4-H participants. Journal of Agricultural Education, 4Х3), 70-80.

Radhakrishna, R.B., Everhart, L., \& Sinasky, M. (2006). Attitudes of 4-H participants about 4-H competitive events. Journal of Extension, 44(6).

Smith, K.L., \& Collins, C. (1988). Attitudes toward competition in a youth organization. Journal of the American Association of Teacher Educators in Agriculture, 29(2), 40-48.

Weber, J.A., \& McCullers, J.C. (1986). The blue ribbon: An American way of life. The effects of competition and rewards in 4-H. Journal of Extension, 24, 20-22.

Wessel, T., \& Wessel, M. (1982). 4-H: An American Idea. Chevy Chase, MD: National 4-H Council.

(C) Copyright of Journal of Youth Development $\sim$ Bridging Research and Practice. Content may not be copied or emailed to multiple sites or posted to a listserv without copyright holder's express written permission. However, users may print, download or email articles for individual use. 